\title{
Export Competitiveness of Central and Eastern Europe Since the Enlargement of the EU
}

\author{
John Gilbert* \\ Department of Economics \& Finance \\ Utah State University
}

\author{
Eva Muchová \\ Department of Economic Theory \\ University of Economics in Bratislava
}

\begin{abstract}
We use constant market share (CMS) analysis to decompose changes in the export shares of the Central and Eastern European (CEE) economies in the period since the 5th enlargement of the European Union (EU) and measure changes in export competitiveness. We find that the CEE transition economies have generally increased their world export competitiveness, but gains in market share have been tempered by a poor match between both the commodity and regional export profiles of most of the CEE economies and the changes in the world import profile, and by generally slow adaptation of the region to changes in the latter on both the commodity and regional dimensions. Changes in export competitiveness in the region overall are instead driven largely by expansions of market share within the EU. Using a new method we show that only a small proportion of the change in the trade share is attributable to changes in the extensive margin. We discuss possible policy implications.
\end{abstract}

$J E L: \mathrm{F} 14$

Keywords: Export growth, CMS, Eastern Europe

${ }^{*}$ Contact: Department of Economics and Finance, Jon M. Huntsman School of Business, Utah State University, 3565 Old Main Hill, Logan, UT 84322-3565. Ph: 435-797-2314. E-mail: jgilbert@usu.edu. The authors would like to thank Peter Leško for research assistance and Sandra Hlivnjak for helpful comments. This paper was prepared under project ITMS 26140230005 and co-financed by the European Union. 


\section{Export Competitiveness of Central and Eastern Europe Since the}

\section{Enlargement of the EU}

\section{Introduction}

In the early 1990s the Central and Eastern European countries (the Czech Republic, Estonia, Hungary, Latvia, Lithuania, Poland, Slovakia, and Slovenia, hereafter the CEE) began the historic process of transforming their planned economic systems into market economies. The set of changes necessary to achieve this economic transition would go well beyond any previous reforms, because they implied not just a change in the rules by which the system operated, but a change in the system itself, from socialism to capitalism. This was political and economic change of the most profound nature.

Changes in the international trade regime played an important part of the transition and early on in the transition process the CEE countries established the objective of joining the European Union (EU). While the motivations for joining the EU clearly had a strong political component on both sides, as the CEE economies sought to consolidate their fledgling democracies and the EU (and the United States) sought to limit the influence of Russia, it was certainly also the case that the joining the EU was seen as a means to help ensure the economic success of the Central and Eastern European region.

The objective of joining the EU was achieved in 2004. The 5th enlargement of the Union was the largest single expansion in terms of both people and number of countries. In addition to freeing international trade flows, labor movement has been gradually freed, and five of the economies have also joined the eurozone (Slovenia, Slovakia, Estonia, Latvia and, most recently, Lithuania). Hence, the process of economic integration of the CEE with the EU is now thoroughly entrenched. ${ }^{1}$

\footnotetext{
${ }^{1}$ The Treaty of Accession to the EU was signed in 2003, allowing the eight CEE countries, to join the EU, along with Cyprus and Malta, in early 2004. Movement of labor from the new CEE members was initially limited by national policies in the former EU member states until 2006, a response to concerns over workers from CEE suddenly flooding of labor markets in the EU15. Restrictions on the movement of citizens were removed in 2011, leaving entry into the eurozone as the last remaining aspect of economic integration for most of the economies. Slovenia was the first of the economies to adopt the Euro, in 2007, followed by Slovakia in 2009, and Estonia in 2011. Latvia joined the eurozone in early 2014, followed by Lithuania in 2015, but the remaining CEE countries currently appear cool to the idea of currency union.
} 
Did joining the EU help to improve export competitiveness in the CEE economies as anticipated? And if so by how much? More than a decade has now passed since the 5th enlargement, making quantitative assessment feasible. Hence, it is important to consider how export competitiveness has changed in the economies of the CEE economies in the period since the enlargement occurred, and the policy lessons that arise thereof.

A large number of studies have attempted to estimate the effect of the EU, and in particular the formation of the eurozone, on trade patterns, with most adopting the gravity model approach (early papers include Rose, 2000, Barr et al., 2003, Flam and Nordstrom, 2006, and de Nardis et al., 2008). Rose (2009) found that trade increased by between 8 to 23 percent as a result of the eurozone, while Baldwin (2006) finds somewhat more modest results. The most recent metaanalysis by Cindea and Cindea (2012) finds effects in the same range as Rose (2009). However, these studies focus on aggregate trade and the experience of the pre-expansion EU members (i.e., the EU15).

A smaller number of studies have also addressed changes in export competitiveness in individual CEE economies. In terms of the Baltic states, Reiljan and Ivanov (2000) examined Estonian foreign trade prior to accession, while Viilmann (2003) applies constant market share analysis to the case of Estonia. Saboniene (2009) adopts a revealed comparative advantage approach to analyzing export competitiveness among the Baltic states over the period 2001-7, arguing that Lithuanian, Latvian and Estonian exports remain dependent on the traditional industries, while exports of mediumhigh technology and high technology industries have gradually increased. Kaluzynska et al. (2009) look at the case of Poland, arguing that accession led to a substantial increase in trade with the EU, mostly in agricultural and food products. On the other hand, Szemlér (2009) argues that EU membership did not change the pattern of Hungary's trade with the original EU members, but rather led to increased trade within the previous members of CEFTA (the Central European Free Trade Agreement) as a result of allowing increasing FTA coverage and agricultural trade. Vagác (2001) considered the trade effect of EU on the Slovak Republic, while the effect of joining the Euro on the Slovak economy was considered by the National Bank of Slovakia (2006), with an emphasis on the sectoral pattern of competitive pressure.

In this paper we systematically examine the export performance of all of the eight CEE economies over the period since joining the EU using a consistent dataset and method. As such, the 
work extends the earlier country-specific studies and complements Besedes (2011), who considers the trade of transition economies between 1996 and 2006, with a focus on export shares, intensive and extensive margin changes, and export hazard. We measure changes in competitiveness using the Constant Market Shares norm approach (CMS). The paper contributes to the literature by providing the first decomposition of the sources of export share growth for the Central and Eastern European economies since the 2004 EU expansion, of which we are aware, using CMS analysis. The approach decomposes the growth in a country's exports or export shares into components that correspond to holding its market shares constant at various levels. These components can (under certain conditions) be associated with changes in competitive positions, and success in adapting to new markets along different dimensions. ${ }^{2}$ In addition to the new application, we extend the CMS approach by showing how it can be adapted to evaluate changes in intensive and extensive margins of trade (see also Hloušek, 2009).

A number of interesting results emerge from our analysis. All of the CEE economies have increased their world export market share over the post-enlargement period. Gains in world market share have, however, while certainly associated with increased competitiveness, been limited by a poor match between both the commodity and regional export profiles of most of the CEE economies and the changes in the world import profile, and by generally slow adaptation of the CEE economies to changes in the world economy on both the commodity and regional dimensions. By decomposing changes across regions, we see that the movements in CEE export competitiveness overall are instead driven largely by expansions of market share within the EU. This suggests that joining the EU was indeed a success from the perspective of expanding market share, but that the potential for future increases in export competitiveness may be limited by slowing growth in Western Europe. We also find that relatively little change in CEE market share has occurred along the extensive margin for goods. Finally, our analysis may shed some light on how recent developments, such as Brexit, may impact the trade patterns of the CEE economies.

The remainder of the paper is structured as follows. In the next section we lay out our method of analysis and discuss its foundations and interpretation. We then describe the dataset to which

\footnotetext{
${ }^{2}$ Introduced in the international trade context by Tyszynski (1951), CMS was extended and popularized by Leamer and Stern (1970), with further development by Richardson (1971) and Fagerberg and Sollie (1987), among others. The technique has recently been applied to export growth of a number of broad aggregate regions by Widodo (2010), and to US export growth in Gilbert (2010).
} 
we apply the technique. In Section 3 we present our results and discuss some policy implications. Concluding comments and suggestions for future lines of inquiry follow.

\section{Method and Data}

The theoretical foundations underlying utilizing a constant-share norm to evaluate changes in export competitiveness follow directly from consideration of relative export demand. Suppose that the relative demand within a particular market for exports from any two alternative sources (1 and 2) is a function of the relative price, such that $x_{1} / x_{2}=f\left(p_{1} / p_{2}\right)$, where $x_{i}$ is the export volume and $p_{i}$ is the price. We can think of region 1 as being the region of interest, and region 2 as being the rest of the world. Since the market share of source 1 is defined as $\theta_{1}=\left(1+p_{2} x_{2} / p_{1} x_{1}\right)^{-1}$, this implies that $\theta_{1}=\left(1+g\left(p_{1} / p_{2}\right)\right)^{-1}$ where $g=\left(p_{2} / p_{1}\right) f\left(p_{1} / p_{2}\right)^{-1}$. In other words, the export share of source 1 will remain constant except to the extent that the relative price varies, which establishes the general rationale for using a constant share norm to evaluate changes in competitiveness. Deviations from the norm should reflect changes in relative prices (see Leamer and Stern, 1970).

Suppose further that we are willing to posit that relative demand can be represented by a constant elasticity function, i.e., that $f=\left(p_{1} / p_{2}\right)^{-\sigma}$ where $\sigma$ is the elasticity of substitution (assumed greater than unity). Then $g=\left(p_{1} / p_{2}\right)^{\sigma-1}$. In this case it can be shown that $\hat{\theta_{1}}=-\left(1-\theta_{1}\right)(\sigma-1)\left(\hat{p}_{1}-\hat{p}_{2}\right)$, where a circumflex denotes a proportional change. These expressions are familiar, since they are the same as those used in implementing the two-stage demand system commonly adopted in the computable general equilibrium literature and elsewhere. Hence, the constant share norm holds exactly under Armington preference assumptions (see Merkies and van der Meer, 1988). ${ }^{3}$

Having established the general validity of the principle, we now turn to the mechanics of implementation, since there are a number of alternatives. The approach we use is based on Fagerberg and Sollie (1987). Consider first the regional pattern of a country's exports. Let the set $\mathbf{R}$, indexed by $r$, be the regions to which the country under consideration may export. Let $x$ be the total exports of that country, and $X$ be total world exports. Let $x_{r}$ be total exports from the country

\footnotetext{
${ }^{3}$ Of course, an Armington structure does impose some moderately restrictive assumptions on the nature of demand. Ahmadi-Esfahani (2006) provides further discussion of the theoretical foundations and the conditions under which they are valid. The key empirical question is the level at which the norm is applied - equivalent to the general problem of market definition.
} 
under study to region $r$, and $X_{r}$ be total exports from the world to region $r$, so $x=\sum_{r \in \mathbf{R}} x_{r}$ and $X=\sum_{r \in \mathbf{R}} X_{r}$. The country's share of total world exports is $\theta=x / X$. Similarly, $\theta_{r}=x_{r} / X_{r}$ is the share of the country's exports to region $r$ in total world exports to region $r$. Finally, let $\delta_{r}=X_{r} / X$ be the share of total world exports that are destined for market $r$. Evidently, $\theta=\sum_{r \in \mathbf{R}} \theta_{r} \delta_{r}$ (this is an identity). The change in the country's share of world trade between any two periods 0 and 1 , $\Delta \theta=\theta^{1}-\theta^{0}$, can therefore be written:

$$
\Delta \theta=\sum_{r \in \mathbf{R}} \Delta \theta_{r} \delta_{r}^{0}+\sum_{r \in \mathbf{R}} \Delta \delta_{r} \theta_{r}^{0}+\sum_{r \in \mathbf{R}} \Delta \theta_{r} \Delta \delta_{r}
$$

where a Laspeyres index is used throughout. The first term captures expansions in export market shares relative to the initial world market shares - capturing increases in competitiveness at the level of the regional market. The second term captures the effect of growth in the size of the regional markets at the initial shares, while the third is the interaction between the first two.

We can do something similar along the commodity dimension. Let the set of traded goods be denoted $\mathbf{I}$, which is indexed by $i$. Let $x_{i}$ be the total exports of good $i$ from the country under study, so that $x=\sum_{i \in \mathbf{I}} x_{i}$, and $X_{i}$ be total exports of good $i$ from the world, so $X=\sum_{i \in \mathbf{I}} X_{i}$. Let $\theta_{i}=x_{i} / X_{i}$ represent the country's share of the world market for $i$, and $\beta_{i}=X_{i} / X$ represent the share of $i$ in world trade. As above, $\theta=\sum_{i \in \mathbf{I}} \theta_{i} \beta_{i}$ is an identity. Hence, it is straightforward to show that:

$$
\Delta \theta=\sum_{i \in \mathbf{I}} \Delta \theta_{i} \beta_{i}^{0}+\sum_{i \in \mathbf{I}} \Delta \beta_{i} \theta_{i}^{0}+\sum_{i \in \mathbf{I}} \Delta \theta_{i} \Delta \beta_{i}
$$

The interpretation of this expression is the same as for (1), but with the market defined at the commodity level.

Finally, the regional and commodity decompositions can be integrated, defining the market share norm at the region/commodity level. To see this, let $x_{i r}$ be exports from the country under study of good $i$ to region $r$. Evidently, $x_{r}=\sum_{i \in \mathbf{I}} x_{i r}$ and $x_{i}=\sum_{r \in \mathbf{R}} x_{i r}$. Defining the share of exports from the country under study of good $i$ to country $r$ in world exports of $i$ to $r$ as $\theta_{i r}=x_{i r} / X_{i r}$ and the share of world exports of $i$ to $r$ in world total exports to $r$ as $\beta_{i r}=X_{i r} / X_{r}$, we can implement the commodity decomposition on a regional basis. It follows that (2) can be 
written for each destination region:

$$
\Delta \theta_{r}=\sum_{i \in \mathbf{I}} \Delta \theta_{i r} \beta_{i r}^{0}+\sum_{i \in \mathbf{I}} \Delta \beta_{i r} \theta_{i r}^{0}+\sum_{i \in \mathbf{I}} \Delta \theta_{i r} \Delta \beta_{i r} \quad \forall r \in \mathbf{R}
$$

Substituting (3) into (1) yields the complete decomposition of the change in the country's world market share:

$$
\begin{array}{rrr}
\Delta \theta & =\sum_{r \in \mathbf{R}} \sum_{i \in \mathbf{I}} \Delta \theta_{i r} \beta_{i r}^{0} \delta_{r}^{0} & \text { (Market Share Effect) } \\
& +\sum_{r \in \mathbf{R}} \sum_{i \in \mathbf{I}} \Delta \beta_{i r} \theta_{i r}^{0} \delta_{r}^{0} & \text { (Commodity Composition Effect) } \\
& +\sum_{r \in \mathbf{R}} \sum_{i \in \mathbf{I}} \Delta \theta_{i r} \Delta \beta_{i r} \delta_{r}^{0} & \text { (Commodity Adaptation Effect) } \\
& +\sum_{r \in \mathbf{R}} \Delta \delta_{r} \theta_{r}^{0} & \text { (Region Composition Effect) } \\
& +\sum_{r \in \mathbf{R}} \Delta \theta_{r} \Delta \delta_{r} & \text { (Region Adaptation Effect) }
\end{array}
$$

This is the complete decomposition we use. The first term is the one of primary interest. The market share effect shows the impact of changes in the market shares by commodity and destination, weighted by the commodity composition of each destination and the regional composition of world trade in the base year. It can be thought of as the increase in competitiveness having controlled for the initial commodity and regional composition of the country's exports - i.e., relative to the constant share norm defined at the commodity/regional level with the world export pattern as the base. Term two, the commodity composition effect, shows to what extent the change in market share can be explained by the initial commodity composition of the country's exports. It will be positive if the initial commodity composition of exports favors those goods in which world trade is growing relatively rapidly. The commodity adaptation effect (the third term) shows to what extent the country has been successful in adapting the commodity composition of its exports to meet changes in world demand. The region composition effect (four) shows to what extent the change in market share can be explained by the initial regional pattern of the country's exports. It will be positive if the regional pattern of exports favors countries the imports of which are growing relatively quickly. Finally, the region adaptation effect (five) can be interpreted as showing to 
what extent the country has been successful in adapting the regional composition of its exports to meet changes in the world regional import demand structure.

In order to compute the decomposition, we need to construct appropriate matrices of exports. Data on merchandise trade is drawn from the United Nations' COMTRADE database. The export matrices are constructed for the years 2001-2003 (just before the expansion) and 2013-2015. Hence, we are considering changes in the export pattern over the period since the EU enlargement. ${ }^{4}$ Specifically, we use the reported export/import data in the HS-1996 classification, at the chapter level (i.e., 2 digits). This gives us a total of 98 merchandise export categories. ${ }^{5}$ Although we conduct our analysis for the CEE countries, and for the EU15, we maintain the maximum available number of export destinations - a total of 244 countries in the database. ${ }^{6}$ This is a greater level of disaggregation than that used in most previous studies using the CMS method, in particular on the regional side. Since the method is subject to aggregation bias (see Ahmadi-Esfahani, 2006) working with disaggregate data is preferred. ${ }^{7}$

The world market export shares (as a percentage) for the countries are presented in Table 1, along with the average over 2001-2003 and 2013-2015. All of the CEE economies are relatively small in terms of world trade, with the largest being Poland and the Czech Republic, and the smallest Estonia and Latvia. In total, exports of the CEE economies were around 1.1 percent of world exports prior to the expansion, and around 1.6 percent by the end of the period. The average world market share rose over the period for all of the CEE economies, but for comparison purposes

\footnotetext{
${ }^{4}$ Changes in the total value of exports for the CEE economies since the expansion have been substantial. The smallest increases are for Slovenia and Hungary, the values of merchandise exports of which just over doubled, while the largest increases are for Latvia and Lithuania, the merchandise exports of which nearly quadrupled over the period. On average the nominal value of exports more than tripled over the period for the group as a whole.

${ }^{5}$ Although raw materials including mineral fuels remain a significant source of export revenue for all of the economies, the majority of merchandise exports from the region are now in the categories of electrical machinery and parts, mechanical appliances, and vehicle parts. The share in these categories share has been expanding, suggesting that CEE is integrating with global supply chains.

${ }^{6} \mathrm{CEE}$ exports are destined predominantly for the EU (ranging from a low of 60 percent for Lithuania to a high of 78 percent for the Czech Republic, with most countries over 70 percent). Economies within the EU fill the majority of the top ten export destinations for all of the CEE, with Germany being by far the most important export market overall, followed by France, the United Kingdom and Italy. Exports within the CEE are also significant, ranging between 8 percent for Hungary and 25 percent for Slovakia, the latter figure being dominated by the Czech Republic. Of the countries outside of the EU, the Russian Federation is the most important market (in particular for Latvia, the Czech Republic and Poland) followed by the United States (although the latter accounted for only around 3.2 percent of the exports of the economies overall in 2014, down from 4.2 percent in 2003).

${ }^{7}$ Since import data is generally regarded as more reliable than export data, we use the import data (the export mirror) as our base. We use the reported export data to fill any gaps. A set of GAMS programs was written to compile and balance the raw data and make the required computations. The datasets and programs are available from the authors on request.
} 
fell markedly for the EU15.

Table 1. World Market Shares of CEE Economies 2001-203 and 2013-2015 (percentage)

\begin{tabular}{lrrr|r}
\hline & & & & Average \\
& 2001 & 2002 & 2003 & $2001-2003$ \\
\hline Czech Republic & 0.26 & 0.29 & 0.32 & 0.29 \\
Estonia & 0.03 & 0.03 & 0.03 & 0.03 \\
Hungary & 0.25 & 0.26 & 0.27 & 0.26 \\
Latvia & 0.02 & 0.02 & 0.02 & 0.02 \\
Lithuania & 0.03 & 0.04 & 0.04 & 0.04 \\
Poland & 0.27 & 0.29 & 0.33 & 0.30 \\
Slovakia & 0.10 & 0.12 & 0.14 & 0.12 \\
Slovenia & 0.07 & 0.08 & 0.08 & 0.08 \\
EU15 & 16.93 & 16.98 & 17.29 & 17.06 \\
\hline & & & & Average \\
& 2013 & 2014 & 2015 & $2013-2015$ \\
\hline Czech Republic & 0.40 & 0.42 & 0.43 & 0.42 \\
Estonia & 0.04 & 0.05 & 0.04 & 0.04 \\
Hungary & 0.27 & 0.28 & 0.30 & 0.28 \\
Latvia & 0.03 & 0.04 & 0.03 & 0.03 \\
Lithuania & 0.06 & 0.07 & 0.06 & 0.07 \\
Poland & 0.50 & 0.53 & 0.56 & 0.53 \\
Slovakia & 0.20 & 0.20 & 0.20 & 0.20 \\
Slovenia & 0.08 & 0.08 & 0.08 & 0.08 \\
EU15 & 13.42 & 13.37 & 13.47 & 13.42 \\
\hline
\end{tabular}

\section{Results}

The results of computing the market share decomposition (equation 4) are presented in Table 2. The figures are the percentage changes in the market share (i.e., we have divided both sides of equation 4 by the initial market share), with the final column presenting the total percentage change in the average world market share (as given in Table 1). Since export shares at a disaggregate level can fluctuate, and this may impact the results, we smooth the analysis by comparing the average market share over the three year period prior to the expansion (2001-2003) to the three year period $(2013-2015) .^{8}$

\footnotetext{
${ }^{8}$ This is equivalent to calculating the decomposition over the periods 2001-2013, 2002-2014, and 2003-2015, and averaging the results.
} 
Table 2. CMS Analysis of the Merchandise Trade of CEE Economies 2001-2003 vs 2013-2015 (percentage change in average market share)

\begin{tabular}{lrrrrr|r}
\hline Country & MS Effect & CC Effect & CA Effect & RC Effect & RA Effect & Total \\
\hline Czech Republic & 71.9 & -5.6 & -9.1 & -2.9 & -9.6 & 44.8 \\
Estonia & 32.4 & 4.1 & -11.2 & -8.2 & 5.0 & 22.0 \\
Hungary & 22.5 & -5.4 & -3.2 & -8.0 & 1.2 & 7.2 \\
Latvia & 32.1 & 10.7 & -5.2 & -4.0 & 12.3 & 46.0 \\
Lithuania & 67.4 & 8.4 & 2.2 & 2.6 & -3.2 & 77.4 \\
Poland & 109.3 & -1.2 & -12.8 & -4.6 & -12.3 & 78.5 \\
Slovakia & 88.4 & -4.1 & -7.2 & -4.0 & -5.9 & 67.1 \\
Slovenia & 19.5 & -3.2 & -2.2 & -6.2 & -5.4 & 2.5 \\
EU15 & -11.2 & -2.1 & -0.2 & -7.1 & -0.7 & -21.3 \\
\hline
\end{tabular}

A number of interesting patterns emerge from the decomposition. First, as we noted above, all of the CEE economies increased their share of world merchandise exports over the period, with the most significant changes in Poland, followed by Lithuania, Slovakia and Latvia. Changes in Slovenia and Hungary were much smaller. The average world export market share for the EU15 economies, by contrast, declined substantially over the period.

Now consider the sources of the changes. The primary effect of interest is the market share effect (column 1), which provides the normalized competitiveness measure. In all of the CEE countries we measure positive increases in competitiveness - i.e., in the post-expansion period all of the CEE economies expanded their export market share faster than the world average, after controlling for both the initial commodity and regional composition of trade. The largest increases in competitiveness were observed in Poland, Slovakia and the Czech Republic. We also observe a substantial decline in competitiveness in the EU15 on average.

Note that in the case of all of the CEE economies except Lithuania, the market share effect is actually larger than the increase in the average world export share. This means that other factors tended to limit the ability of the CEE economies to exploit their increased competitiveness. Considering the remaining columns, we see that the commodity composition effects are generally negative, with the only significant exceptions being Latvia and Lithuania, implying that the region's commodity export profile at the beginning of the period was generally poorly matched to the changes in the commodity composition of world trade, and this limited the ability of the economies to expand their export shares. Moreover, none of the CEE economies except Lithuania were 
successful at adapting the commodity profile of their merchandise exports to changes in the world commodity profile of imports, relative to the world average. Fagerberg and Sollie (1987) note a tendency for countries with positive commodity composition effects to adapt less well than countries with negative commodity composition effects, perhaps reflecting complacency, but that pattern does not seem to be borne out in the CEE experience. Instead it seems to be a low level of adaptability across the board. ${ }^{9}$

The relatively small change competitiveness for Slovenia over the period of which is perhaps somewhat surprising, given that it is generally regarded as an early reformer and was one of the first economies in the region to adopt the Euro. We see that Slovenia has particularly strong negative commodity composition effect (and also strong and negative regional composition and regional adaptation effects, perhaps a reflection of historically close connections with the economies in the Western Balkans).

In terms of sectors that have been most successful in gaining world market share, holding market characteristics constant (i.e., those sectors that appear to have increased their competitiveness), we find that the categories of electrical machinery and parts, mechanical appliances, and vehicle parts dominate in the other CEE economies. On the other hand, these same sectors (along with wood products) have actually been among the slower growing in terms of world imports, and have thus contributed negatively to market share through the commodity composition (and adaptation) effects.

On the regional composition side we see a very similar pattern to that which we observed on the commodity dimension. Lithuania again seems to to be the only economy among the CEE countries to have benefited from a regional export profile that matched the faster growing economies in world trade. For the other CEE economies the regional composition effect is negative, quite strongly so in the case of Hungary and Estonia. Interestingly, Lithuania is the country with the lowest share of

\footnotetext{
${ }^{9}$ To gain further insights into what is driving the results, we broke down the first three terms of the decomposition by merchandise export category. Doing so allows us to rank the importance of each category for the overall component. The analysis reveals that CEE as a whole has benefited from world growth in the imports of oil and petroleum, most notably Lithuania and Estonia, and also iron and steel (in particular Latvia). The region has also been most successful in adapting to world markets in terms of exports of oil and petroleum, especially Lithuania and Estonia. Hence, the difference between the results observed for other countries in the region and Lithuania seems to be largely explained by changes in the oil and petroleum market. To verify that the patterns observed for Estonia and Lithuania are driven more by changes in oil markets, we conducted the decomposition excluding oil and petroleum products (as in Fagerberg and Sollie, 1987). While the patterns for the other CEE countries are largely unchanged, the commodity adaptation effect for these two economies is sharply lower.
} 
exports to the EU. Indeed, Lithuania is much more dependent on exports to the Russian Federation than any of the other economies under consideration. ${ }^{10}$

Adaptation to changes in the regional market among the CEE economies is mixed, with strong positive adaptation for Estonia and especially Latvia, but negative effects for most other economies. So CEE economies have not generally been sucessful at adpating their exports to target fast-growing export markets. Again, a negative correlation between regional composition and regional adaptation does not appear for the CEE economies over this period.

In sum, it seem that CEE as a whole won market share at the expense of the rest of the world in the post-EU expansion period by increasing its competitiveness, in spite of a generally poor match between its commodity and regional export profiles at the start of the period, and relatively weak adaptation along both dimensions. The next key question is of course, why? Because CMS is based on an identity, it cannot tell us anything causal. There are multiple theories that can be consistent with the observations. Is it because of improved productivity? Or is it reflecting preferential access (i.e., trade diversion)? Or is it something else? CMS can suggest places to look. One way to do so is to partition the effects by region. In Table 3 we have broken down the percentage changes from Table 2 into three components: those attributable to the CEE economies themselves, those attributable to the remaining economies in the EU28, and those attributable to the rest of the world.

Again a number of interesting patterns emerge. First consider the regional composition effect. Recall that this is positive if the economies in question have benefited in terms of market share by having a regional export profile that is dominated by relatively fast growing markets. The preexpansion members of the EU are relatively slow growing, and this has had a negative effect on the world export share of most of the economies, as opposed to positive effects from the CEE and rest of world partitions. In other words, a strong reliance on EU markets has actually hurt the CEE economies in terms of market shares, relative to the world average. Similarly, the adaptation effect is generally negative for the EU partition and positive for the others.

Yet, changes in exports to the EU have, for the most part, contributed positively to the overall change in market share of the CEE economies. It is expansion of the market shares that clearly dominates, in stark contrast to the other partitions. In other words, a number of the CEE economies

\footnotetext{
${ }^{10}$ Again, this result disappears if we exclude oil from the analysis.
} 
Table 3. CMS Analysis of the Merchandise Trade of CEE Economies 2001-2003 vs 2013-2015 by Region (percentage change in average market share)

\begin{tabular}{|c|c|c|c|c|c|c|}
\hline Country & MS Effect & CC Effect & CA Effect & RC Effect & RA Effect & Total \\
\hline \multicolumn{7}{|c|}{ Central and Eastern Europe } \\
\hline Czech Republic & 1.0 & -0.1 & -0.1 & 6.5 & -1.2 & 6.1 \\
\hline Estonia & 4.4 & -0.1 & -0.2 & 4.2 & 2.4 & 10.6 \\
\hline Hungary & 1.3 & 0.4 & -0.3 & 2.6 & 0.8 & 4.8 \\
\hline Latvia & 20.1 & 0.5 & 1.9 & 3.3 & 9.5 & 35.3 \\
\hline Lithuania & 11.9 & 1.7 & 2.7 & 5.8 & 4.9 & 27.0 \\
\hline Poland & 9.3 & 0.4 & 0.1 & 2.7 & 2.2 & 14.6 \\
\hline Slovakia & 8.1 & 0.6 & 1.1 & 5.4 & 0.0 & 15.2 \\
\hline Slovenia & 0.9 & -0.4 & 0.2 & 2.6 & -1.0 & 2.4 \\
\hline EU15 & -0.7 & -0.1 & 0.0 & 1.2 & -0.3 & 0.1 \\
\hline \multicolumn{7}{|c|}{ Rest of European Union } \\
\hline Czech Republic & 58.5 & -5.2 & -7.5 & -13.7 & $\begin{array}{l}-10.6 \\
\end{array}$ & 21.5 \\
\hline Estonia & 18.0 & -1.7 & -4.9 & -15.7 & -2.2 & -6.4 \\
\hline Hungary & 14.4 & -5.0 & -2.1 & -14.1 & -2.1 & -8.8 \\
\hline Latvia & 5.2 & 6.2 & -4.9 & -15.5 & -1.2 & -10.2 \\
\hline Lithuania & 28.2 & 5.7 & 0.6 & -13.0 & -8.2 & 13.4 \\
\hline Poland & 78.0 & -2.2 & -8.0 & -14.6 & -16.0 & 37.3 \\
\hline Slovakia & 63.9 & -4.0 & -9.0 & -12.2 & -12.2 & 26.5 \\
\hline Slovenia & 20.5 & -3.7 & -1.7 & -15.5 & -3.8 & -4.1 \\
\hline EU15 & -5.0 & -1.4 & -0.1 & -14.3 & 1.6 & -19.2 \\
\hline \multicolumn{7}{|l|}{ Rest of World } \\
\hline Czech Republic & 12.4 & -0.3 & -1.5 & 4.3 & 2.2 & 17.2 \\
\hline Estonia & 10 & 5.9 & -6.1 & 3.3 & 4.8 & 17.8 \\
\hline Hungary & 6.8 & -0.8 & -0.8 & 3.5 & 2.5 & 11.2 \\
\hline Latvia & 6.8 & 4 & -2.2 & 8.2 & 4 & 20.9 \\
\hline Lithuania & 27.3 & 1 & -1.1 & 9.8 & 0.1 & 37 \\
\hline Poland & 22 & 0.6 & -4.9 & 7.3 & 1.5 & 26.6 \\
\hline Slovakia & 16.4 & -0.7 & 0.7 & 2.8 & 6.3 & 25.4 \\
\hline Slovenia & -1.9 & 0.9 & -0.7 & 6.7 & -0.6 & 4.2 \\
\hline EU15 & 3.8 & 1.1 & 0.1 & 11.9 & -1.4 & 15.5 \\
\hline
\end{tabular}


have expanded their market share in the pre-expansion EU countries at a much faster rate than in other countries, having controlled for the initial pattern of commodity and regional trade. They are increasing their competitiveness inside a set of slow growing economies.

If the change in market share was due to generalized changes in the productivity of the CEE economies, we might expect to see a similar pattern of competitive effects across the partitions. ${ }^{11}$ However, this does not seem to be the case for all of the economies in question (most clearly not for the Czech Republic, Poland, Slovakia and Slovenia). One possibility is clearly trade diversion effects, i.e., preferential access allowing market share expansion at the expense of other countries. However, given that free trade was already largely in place under the European Association Agreements between 5 and 10 years prior to the enlargement, it is not clear why trade preferences would have a dramatic impact over this period.

Another possible explanation is increased integration into production networks driven by geographical proximity. It is not a coincidence that two of the countries where the pattern is strongest share a border with Germany, and all are relatively close to the center of Europe. The significance of changes in vehicle parts and electrical parts noted above is suggestive, as these are sectors where global supply chains are particularly important. The latter view also is supported by the fact that the pattern is not observed for Estonia, Latvia and Lithuania, all countries at the periphery, with much closer ties to the Russian Federation. Indeed the only country for which geography does not seem to be a plausible driver of the differences is Hungary. Our results for Hungary are generally consistent with the observation of Szemlér (2009) that EU membership did not have a dramatic effect on Hungarian merchandise trade with the EU members.

When we consider exports from the EU15 to the CEE, we see that there has not been a substantial increase in market share, and that EU15 competitiveness within CEE markets has in fact fallen slightly, as it has within the rest of the EU, while rising slightly in the rest of the world. So expanding the EU has not greatly impacted trade flows into the CEE economies from the original EU members.

Before turning to some of the policy implications, we consider one further breakdown. An important question is whether the changes in market shares are occurring along the intensive or

\footnotetext{
${ }^{11}$ The idea here is closely related to the analysis of Yeats (1998), who argues that an increase in regional orientation that is not matched be a revealed comparative advantage, is an indicator of trade diversion.
} 
the extensive margin, since this helps us to understand whether the economies have been more or less successful at developing entirely new markets. While the commodity and regional composition effects reflect changes in the intensive margin by construction, the market share effect and the two adaptation effects can in fact be further decomposed into components that can capture both intensive and extensive margin changes. To our knowledge, this is the first use of CMS methods in this way.

Consider the regional adaptation effect. We can think of this as being composed as a sum of weighted changes in $\theta_{r}$ where the initial value is positive, and those where it is zero. These capture, respectively, adaptation to existing markets (intensive), and penetration of entirely new markets (extensive). Similarly, the commodity adaptation effect can be broken into a term representing adaptation within existing product markets, and a term representing expansion into new product categories. The market share effect can be broken down in the same way.

The results of conducting this breakdown are presented in Table 4 . What we see is that the majority of the changes in the market share effect have been along the intensive margin, with the highest extensive margin changes for Lithuania and Latvia. In terms of penetrating new regional markets, most of the changes along the extensive margin are greater than those on the intensive margin, indicating that CEE countries have had somewhat better (or perhaps less poor is a more appropriate description) success entering new markets than adapting to changes in existing ones. Latvia has again had more success than most of its neighbors in this regard. In terms of the commodity adaptation effect, which is negative overall for all economies other than Lithuania, we also see somewhat better effects along the extensive than the intensive margin, most notably for Latvia. On the commodity side, the effects for all countries may be somewhat understated by the level of aggregation.

What are the policy lessons here? To us the biggest takeaway from the decompositions is that the CEE economies have for the most part been successful in increasing their export competitiveness with respect to the EU market. However, they have been much less successful in the rest of the world. Their ability to expand market share has therefore in a broad sense been hampered by the commodity and regional composition of their trade. As trade growth in the EU continues to slow relative to other parts of the world, this trend is likely to become exacerbated. To some extent the negative impact that the regional composition of CEE trade has had on market share of course 
Table 4. Extensive and Intensive Margins and Export Share of CEE Economies 2001-2003 vs 2013-2015 by Region (percentage change in average market share)

\begin{tabular}{lrr|r|rr|r|rr|r}
\hline & \multicolumn{4}{c}{ Market Share } & \multicolumn{3}{c}{ Commodity Adaptation } & \multicolumn{3}{c}{ Regional Adaptation } \\
\hline & Ext. & Int. & Total & Ext. & Int. & Total & Ext. & Int. & Total \\
\hline Czech Republic & 1.4 & 70.6 & 72.0 & -0.1 & -9.0 & -9.1 & 0.0 & -9.7 & -9.6 \\
Estonia & 5.2 & 27.2 & 32.4 & 1.2 & -12.4 & -11.3 & 1.1 & 3.8 & 5.0 \\
Hungary & 0.3 & 22.2 & 22.5 & 0.1 & -3.3 & -3.2 & 0.0 & 1.2 & 1.2 \\
Latvia & 7.7 & 24.5 & 32.2 & 5.0 & -10.1 & -5.2 & 2.9 & 9.5 & 12.3 \\
Lithuania & 12.8 & 54.7 & 67.5 & 0.6 & 1.6 & 2.2 & 0.7 & -3.9 & -3.2 \\
Poland & 4.9 & 104.6 & 109.4 & -3.3 & -9.5 & -12.8 & 0.0 & -12.4 & -12.4 \\
Slovakia & 1.1 & 87.4 & 88.5 & 0.1 & -7.3 & -7.2 & 0.0 & -6.0 & -6.0 \\
Slovenia & 1.3 & 18.2 & 19.5 & 0.2 & -2.4 & -2.2 & 0.0 & -5.8 & -5.7 \\
EU15 & 0.0 & -11.2 & -11.2 & 0.0 & -0.3 & -0.3 & 0.0 & -0.8 & -0.8 \\
\hline
\end{tabular}

reflects the regional nature of trade - given trade costs the CEE markets are simply more isolated from the faster growing economies of East Asia and the Pacific, and are tied more closely to the slow growing economies of Western Europe. The CEE economies in fact trade very little with Asia (China accounts for less then 1 percent of exports of most CEE economies, Japan less than that). But trade costs are at least partially endogenous. The EU is certainly trying to improve ties with ASEAN. CEE economies have been skeptical, viewing some of the economies as competitors within the EU market. But if future growth in exports is to be maintained, the CEE economies ultimately will have to turn more toward Asia.

One of the biggest policy shocks to hit the EU since the expansion is of course Brexit. In 2016 the United Kingdom (UK) voted to leave the EU. In 2017 the UK government invoked Article 50 of the Treaty on the European Union. It is due to leave the EU in 2019. How might this affect the CEE economies? We can can some insights by considering the extent to which the effects in the EU partition correspond to the UK. The UK represents between 2.1 and 6.6 percent of CEE export markets, with an average of around 5 percent. While the UK is certainly dwarfed by Germany, it is one of the largest EU destinations. A large proportion of the market share effect is (ranging from a low of 3 percent from Slovenia to 21 percent for Hungary, with most around 15 percent) associated with expansion into the UK market. Moreover, the commodity composition effect for most CEE economies is positive with respect to the UK market. This means that the UK has been a market particularly well-suited to CEE exports, and that the CEE economies have gained much 
more access to the UK over the period than would be expected given the size of the UK in the EU. Certainly the results suggest that Brexit puts future export expansions at risk. ${ }^{12}$

\section{Concluding Comments}

In this paper we have examined the export performance of all of the eight CEE economies over the period since joining the EU in 2004, providing the first decomposition of the sources of export share growth for all of the CEE economies using CMS analysis, and introducing a method of partitioning across regional groups. In addition, we also show how the CMS technique can be extended to describe changes in trade along both extensive and intensive margins.

A number of interesting results emerge from our analysis. We find that all of the transition economies have increased their export competitiveness over the post-expansion period, although only marginally in the case of Slovenia. Gains in world market share on the merchandise side have, however, been limited by a poor match between both the commodity and regional export profiles of most of the CEE economies and the changes in the world import profile, and by generally slow adaptation of the CEE economies to changes in the latter on both the commodity and regional dimensions (although the Baltic states have benefited from and adapted to changes in energy markets). Some economies have done better adapting on the extensive margin than the intensive, but in general expansion of market share has occurred on the intensive margin. Our analysis is limited in to some degree by aggregation, and it would be useful to reconsider some of the results with more detailed data.

Changes in export competitiveness overall are driven largely by expansions of market share within the EU. Given the commodity composition of changes in export competitiveness, this is perhaps driven by increased integration into European production networks, especially for those economies that are closer to the center of Europe. In this sense, the objective set out by the CEE economies has been met. But the results highlight a danger. The EU economies have been very slow growing, and CEE improvements in competitiveness vis-a-vis the EU have not been matched with respect to the rest of the world. Potential for future growth may be much more limited. Future work might usefully explore the relationship between the measure increases in competitiveness

\footnotetext{
${ }^{12}$ Interestingly, there have been reports that Britain is mulling joining the Trans-Pacific Partnership, suggesting a desire to link more with Asian markets.
} 
and possible driving factors in each of the CEE economies. The generally poor adaptation of the CEE economies to changes in the structure of world trade on both the commodity and regional dimensions is also a subject worthy of further investigation. 


\section{References}

Ahmadi-Esfahani, F.Z. (2006) "Constant Market Shares Analysis: Uses, Limitations and Prospects" Australian Journal of Agricultural and Resource Economics 50:510-26.

Baldwin, R. (2006) “The Euro's Trade Effects” ECB Working Paper 594.

Barr, D., F. Breedon and D. Miles (2003) "Life on the Outside: Economic Conditions and Prospects Outside Euroland" Economic Policy 18:573-613.

Besedeš, T. (2011) "Export Differentiation in Transition Economies" Economic Systems 35:25-44.

Cindea, I.M. and M. Cindea (2012) "The Euro Effect on International Trade" Social and Behavioral Science 58:1267-72.

de Nardis, S., R. De Santis and C. Vicarelli (2008) “The Euro's Effects on Trade in a Dynamic Setting" European Journal of Comparative Economics 5:73-85.

Fagerberg, J. and G. Sollie (1987) "The Method of Constant Market Shares Analysis Reconsidered" Applied Economics 19:1571-83.

Flam, H . and H. Nordstrom (2006) "Trade Volume Effects of the Euro: Aggregate and Sector Estimates" Stockholm University, Institute for International Economic Studies, Seminar Paper 746.

Gilbert, J. (2010) "Notes on Constant Market Share Analysis of a Decade of US Export Growth" Report prepared for the Peterson Institute for International Economics.

Hloušek, M. (2009) "Extensive Margin in International Trade: Empirical Analysis for Visegrad Countries" Mathematical Methods in Economics: 125-30.

Kaluzynska, M., K. Smyk and J. Wisniewski (2009) Five years of Poland in the European Union Office of the Committee for European Integration, Warsaw.

Leamer, E. and R. Stern (1970) Quantitative International Economics (Aldine: Chicago).

Merkies, A.H.Q.M. and T. van der Meer (1988) "A Theoretical Foundation for Constant Market Share Analysis" Empirical Economics 13:65-80. 
National Bank of Slovakia (2006) The Impact of the Introduction of the Euro in the Slovak Economy.

Reiljan, J. and Ivanov, A. (2000) "Estonian Foreign Trade on the Threshold of Joining the EU" Intereconomics 35:274-81.

Richardson, J.D. (1971) "Constant Market Shares Analysis of Export Growth" Journal of International Economics 1:227-39.

Rose, A.K. (2000) "One Money, One Market: The Effect of Currency Unions on Trade" Economic Policy 30:7-46.

Rose, A.K. (2009) "Is EMU becoming an Optimum Currency Area? The Evidence on Trade and Business Cycle Synchronization" in B. Mackowiak, F.P. Mongelli, G. Noblet, F. Smets (eds.) Euro at Ten: Lessons and Challenges European Central Bank, Frankfurt.

Saboniene, A. (2009) "Lithuanian Export Competitiveness: Comparison with other Baltic States" Inzinerine Ekonomika - Engineering Economics 2:49-57.

Szemlér, T. (2009) "The Effects of EU Accession in Hungary" in G. Avery, A. Faber and A. Schmidt (eds.) Enlarging the European Union: Effects on the New Member States and the EU Trans European Policy Studies Association, Brussels.

Tyszynski, H. (1951) "World Trade in Manufactured Commodities, 1899-1950" Manchester School $19: 272-304$.

Vagác̆, L. (2001) "Trade Effects of EU Integration on teh External Position of the Slovak Economy, ACE Phare Project Working Paper.

Viilmann, N. (2003) "Estonia's Export of Goods in 2002 and External Competitiveness" Kroon $\mathcal{E}$ Economy 2.

Widodo, T. (2010) "Market Dynamics in the EU, NAFTA, North East Asia and ASEAN: The Method of Constant Market Shares (CMS) Analysis" Journal of Economic Integration 25:480500.

Yeats, A. (1998) "Does Mercosur's Trade Performance Raise Concerns About the Effects of Regional Trade Arrangements?" World Bank Economic Review 12:1-28. 